\title{
一般口演 6
}

\section{側方滑走運動における下䪽頭の運動様相 \\ 一下顎頭骨変化の有無による検討一}

\author{
Condylar Movements in Lateral Excursion \\ - Comparison between No Bone Change Group and Bone Change Group-
}

○細貝暁子，河野正司，山田一尋*，林 豊彦**，子田 浩

Akiko Hosogai, Shoji Kohno, Kazuhiro Yamada*, Toyohiko Hayashi**, Hiroshi Kota

$$
\begin{array}{r}
\text { 新潟大学大学院医歯学棇合研究科摂食機能再建学分野, *咬合制御学分野 } \\
* * \text { 新潟大学工学部福祉人間工学科 } \\
\text { Department of Removable Prosthodontics, *Department of Orthodontics, } \\
\text { Faculty of Dentistry, Niigata University } \\
\text { **Department of Biocybernetics, Faculty of Engineering, Niigata University }
\end{array}
$$

\section{I. 目 的}

作業側顆頭の運動分析には，全運動軸点や平均的顆頭 点など代表点 1 点のみでの解析が広く行われ, また平均 的顆頭点を中心とした多点解析や顆頭間軸を用いた解析 も行われてきた。しかし実際の顆頭との位置関係はいず れも間接的であり，変形性䫟関節症者や偏位顎の場合は 特に正確性に問題があった。

現在では形態と運動の重ね合わせの精度は向上してい るが未だに具体的データは少なく，また側方滑走運動時 の作業側顆頭のように, 運動量の極めて少ないデー夕解 析には，3-D画像での表示では理解しにくいなどと表 示方法に問題が残されている.

そこでヘリカルCTと顎運動装置の座標系を統一し, 側方滑走運動時の切歯点および作業側顆頭の外側極, 内 側極の運動経路と下顎頭の骨変化の関係について調べた.

\section{II. 方 法}

\section{1. 被験者}

被験者は，実験に同意の得られたボランティアおよび 本学歯学部附属病院矯正科患者15名で, ヘリカルCT画 像の硬組織表示から下顎頭骨変化の診断を行った？そし て, 下顎頭の骨変化がない骨変化無し群 6 名（男子 4 名, 女子 2 名, 平均年齢23.6歳）と, 下顎頭の骨変化を伴う
骨変化有り群 9 名（男子 2 名, 女子 7 名, 平均年齢 24.0 歳）に分類した。

咬合状態は骨変化なし群はすべて個性正常咬合を有 し, 作業側のガイド歯は骨変化なし群では犬歯誘導が 1 名, 両側平衡咬合が 1 名, 犬歯と小臼歯の誘導が残りの 4 名であった。

一方骨変化あり群では骨変化あり群はいずれもアング ル II 級不正咬合（open bite 3 名含む）を有し，犬歯と小 臼歯の誘導が 1 名，小臼歯と大白歯の誘導が 1 名で残り の 7 名は両側大臼歯誘導で, 同部に大きな咬耗が認めら れた。

\section{2. 方 法}

䫟運動測定には 6 自由度顎運動測定器 東京歯材社製)を用い，咬頭嵌合位を始点とする側方滑 走運動往路を測定した.

CT の顎関節画像と顎運動測定で得られる顎関節の 3 次元的運動の位置関係を対応させるために效運動測定点 を特製 face bow ${ }^{1)}$ の先端を 3 次元的にCT画像内に映し 込み 2 つの座標系を統一した。

CT 撮影は，特製 face bow を装着し，咬頭嵌合位での シリコンバイトを咬ませた状態で, 本学歯学部附属病院 所蔵のヘリカル CT (Xvigor Real ${ }^{\circledR}$ : 東芝メディカル社 製）を用い，Reid's base line に平行に，顎関節部スライ ス幅 $1 \mathrm{~mm}$, 管球 1 回転あたりテーブル移動 $1 \mathrm{~mm}$ で撮 


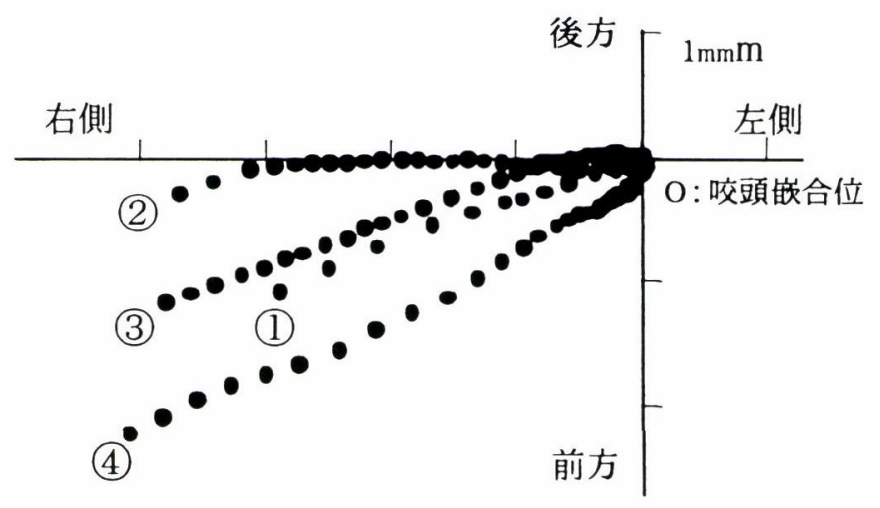

図 1 右側方滑走運動時の切歯路 (水平面観)

(1)骨変化なし群

(2)骨変化あり群 展開角大

(3)骨変化あり群 展開角中

(4)骨変化あり群 展開角小

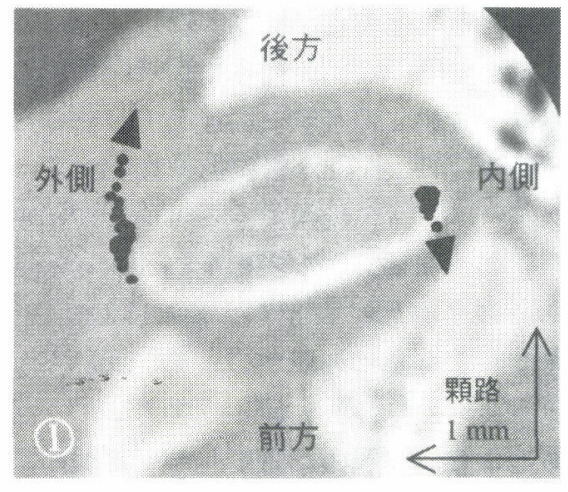

困 2 骨変化なし群の作業側顆頭典型例（回 転型)

外側極と内側極の移動方向が反対で内 側極の移動距離が小さく下顎頭内の内 側極付近に回転中心が存在することが 伺える。
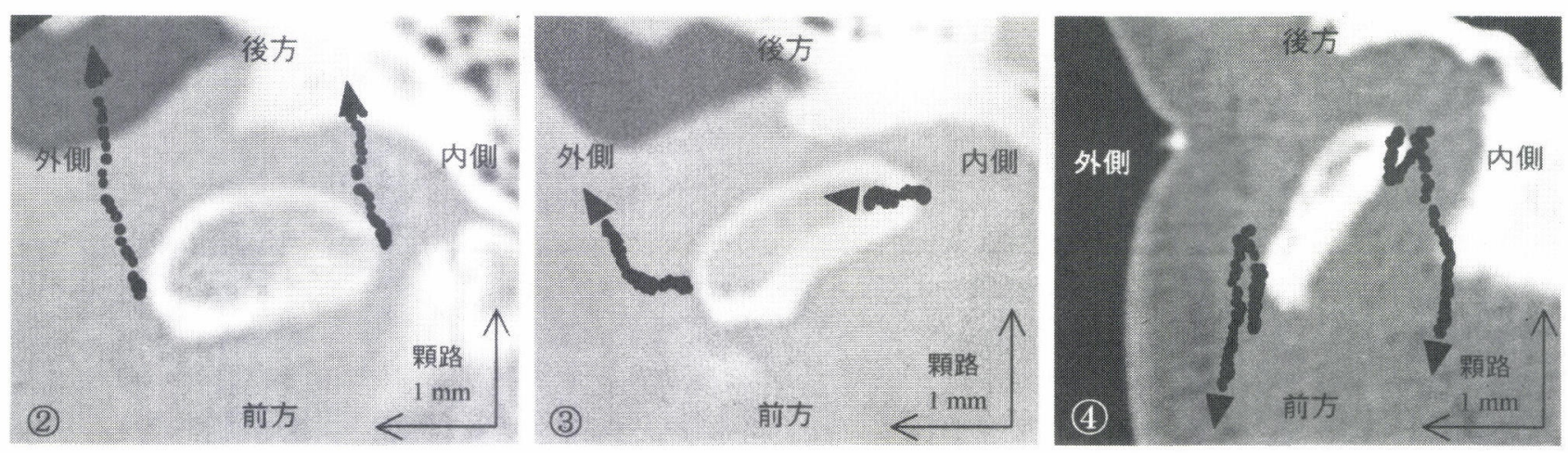

図 3 骨変化あり群の作業側顆頭例

(2)：外側極, 内側極ともに後方へ移動（滑走型）

(3)：外側へサイドシフト後に外側極は後方移動し

内側極はほとんど移動しない（回転型）

(4)：外側極, 内側極ともに前後の反復 移動しその後, 後方移動 (滑走型)

(図はいずれも下顎頭長軸中点での水平断面図. 顆路はCT画像の10倍拡大し便宜的に表示)

影を行った。画像データをwork station（INTAGE ${ }^{\circledR}$ ： K.G.T. 社製）に取り込み， 3 次元計測用再構成画像を 作成し診断と計測に使用した。

そして咬頭嵌合位からガイド歯の切端位までの切歯路 展開角度と両側下顎頭の外側極および内側極の移動距離 と方向を求めた。

\section{III. 結果および考察}

\section{・CTによる画像診断}

CT による顎関節病態診断の結果, 骨変化あり群では, flattening が 9 関節, osteophyte が 6 関節, erosion と osteophyte が混在するものが 3 関節あった。

\section{・切歯路の水平面投影角度による分類}

骨変化無し群の切歯路水平面展開角度を基準に骨変化 あり群を展開角大, 中, 小と分類した.

展開角大を示したものは18関節中 6 関節でどの骨変化 の種類でも大きく後方への滑走型を示した.

展開角中を示したのは 7 関節であったが, 運動初期に 外側に滑走しその後回転型を示すものと, 大きく内側後 方への滑走型を示すものの両者が混在した.

展開角小を示したものは 5 関節で, どの骨変化の種類 
でも大きく前方への滑走型を示した.

側方滑走運動時の切歯路の水平面展開角度と作業側顆 頭の運動は，骨変化の有無と関連していることが示され， 水平面展開角度の大小および経路を観察することで骨変 化のスクリーニングに使用できる可能性が示唆された。

また下顎頭外側極および内側極の 3 次元的移動距離は 骨変化あり群が有意に大きく，また外側極については， 骨変化あり群で有意に外側への移動が認められた。これ は骨変化あり群では，側方滑走運動のガイド歯が大白歯 主体であること，下顎頭の骨変化のため関節窩に占める 下顎頭の大きさの割合が小さいこと, 筋や軟組織の弛緩 などが関連しているのではないかと推察された。しかし 骨变化を伴う顎関節病態が先行したものか誘導歯に関連 した機能運動によるものかは明らかではなく，今後さら
に検討が必要と考えられる。

以上のことから, 側方滑走運動時の作業側顆頭の運動 は, 顎関節病態と関連している可能性が明らかになった。 また，本研究で使用した特製 face bow を用い，形態と 運動の座標系を統一することで, 顎運動と顎関節 3 次元 形態の関連が明らかにされ，従来観察が困難であった作 業側顆頭運動の大きさや方向が定量的に詳細に分析でき ることが示された。

\section{N. 文献}

1) 細貝暁子, 山田一尋, 河野正司ほか. 解剖学的観点 からみた側方滑走運動における作業側顆頭の運動様 相. 顎機能誌 $7: 120-123,2001$. 